\title{
47. STRUCTURE AND EVOLUTION OF THE CENTRAL KERGUELEN PLATEAU DEDUCED FROM SEISMIC STRATIGRAPHIC STUDIES AND DRILLING AT SITE 747
}

\author{
Marc Munschy, ${ }^{2}$ Bernard Fritsch, ${ }^{2}$ Roland Schlich, ${ }^{2}$ Fatmir Fezga, ${ }^{2}$ Yair Rotstein, ${ }^{2,3}$ and Millard F. Coffin ${ }^{4}$
}

\begin{abstract}
The structure and evolution of the Central Kerguelen Plateau (CKP), located between $54^{\circ}-57^{\circ} \mathrm{S}$ and $61^{\circ}-84^{\circ} \mathrm{E}$, is derived from the seismic stratigraphic interpretation of multichannel seismic data and from Ocean Drilling Program results at Site 747. The CKP formed 120-110 m.y. ago by excessive volcanic activity at the axis of the spreading ridge that separated India from Antarctica. At $72 \mathrm{Ma}$, a major pre-rift tectonic episode stretched the basement of the CKP in an east-west direction; the $77^{\circ} \mathrm{E}$ Graben consists of several rift units, somewhat similar to the structure observed in the East African continental rift system. At $42 \mathrm{Ma}$, the breakup between the Kerguelen Plateau and Broken Ridge was accompanied by a period of nonsedimentation of about 15-m.y. duration. After the breakup, the sedimentation was generally continuous but evolved during the Pliocene-Pleistocene in response to climate changes.
\end{abstract}

\section{INTRODUCTION}

The Kerguelen Plateau has been divided into two distinct domains: the Northern Kerguelen Plateau (NKP) and the Southern Kerguelen Plateau (SKP), which are separated by a transition zone called, in this paper, the Central Kerguelen Plateau (CKP) (Schlich, 1975; Houtz et al., 1977). The CKP is located between $54^{\circ}$ and $57^{\circ} \mathrm{S}$; it exhibits a complex bathymetry with a large east-trending spur, the Elan Bank, extending westward from the main plateau over a distance of $600 \mathrm{~km}$ (Fig. 1). The eastern margin of the CKP is a complex junction of the eastern margins of the NKP and SKP, which are dextrally offset about $300 \mathrm{~km}$.

On the bathymetric map (Fig. 1), the CKP appears as a saddle that deepens to about $2500 \mathrm{~m}$ and is centered on $56^{\circ} \mathrm{S}$ and $77^{\circ} \mathrm{E}$. To the north, the limit with the NKP corresponds approximately to the $1000-\mathrm{m}$ isobath. This limit is well marked $10-20 \mathrm{~km}$ south of Heard and McDonald islands by an abrupt slope in the topography, from $200-500$ to 1000 $1500-\mathrm{m}$ depth in an east-west direction. To the northeast, Williams Ridge (Coffin et al., 1986; Ramsay et al., 1986) is a bathymetric high extending $350 \mathrm{~km}$ in a northwest-southeast direction and shallowing to $1000 \mathrm{~m}$ below sea level (mbsl). Williams Ridge is connected to the NKP and is separated from the CKP by a 3500-m-deep depression that corresponds to the northern limit of the Labuan Basin (Coffin et al., 1986; Rotstein et al., 1991). In cross section, Williams Ridge is clearly asymmetric, with an abrupt northeast flank. To the east the CKP gently deepens toward the Labuan Basin from a depth of $2500-4500 \mathrm{~m}$. To the southeast and the south, no particular limit between the CKP and the SKP is apparent on the bathymetric map. To the west, the Elan

\footnotetext{
${ }^{1}$ Wise, S. W., Jr., Schlich, R., et al., 1992. Proc. ODP, Sci. Results, 120: College Station, TX (Ocean Drilling Program).

2 Institut de Physique du Globe, Université Louis Pasteur, Laboratoire de Géophysique Marine (CNRS URA 323), 5 rue René Descartes, 67084 Strasbourg Cedex, France.

${ }^{3}$ Also at Institute for Petroleum Research and Geophysics, P.O. Box 2286, Holon 58120, Israel.

${ }^{4}$ Bureau of Mineral Resources, Geology and Geophysics, GPO Box 378, Canberra ACT 2601, Australia (present address: Institute for Geophysics, University of Texas at Austin, 8701 Mopac Blvd., Austin, TX 78759-8345, U.S.A.).
}

Bank, $600 \mathrm{~km}$ long and $200 \mathrm{~km}$ wide, shallows to $1000 \mathrm{mbsl}$ and is separated from the surrounding ocean basin floor by steep and linear slopes.

The topography on the CKP is generally smooth, and no preferential bathymetric trends were observed except along the $77^{\circ} \mathrm{E}$ Graben (Fig. 2). At this location, several north-south depressions, 200-500 $\mathrm{m}$ deep, were observed. These depressions form the northern part of the $77^{\circ} \mathrm{E}$ Graben, first described by Houtz et al. (1977).

Single-channel seismic (SCS) data from the CKP have been reported on by Houtz et al. (1977), and multichannel seismic (MCS) data were collected in the region by the Australian Rig Seismic (RS) Cruise 02 in 1985 (Ramsay et al., 1986) and by the French Marion Dufresne (MD) Cruise 47 in 1986 (Schlich et al., 1988). During Ocean Drilling Program (ODP) Leg 120 in 1988, one site (Site 747) was drilled in the central part of the CKP (Shipboard Scientific Party, 1989a). In this paper, taking into account the ODP results at Site 747, we describe the structure, stratigraphy, and evolution of the CKP based on MCS and SCS data.

\section{PRINCIPAL RESULTS DEDUCED FROM DRILLING AT SITE 747}

Site $747\left(54^{\circ} 48.68^{\prime} \mathrm{S}, 76^{\circ} 47.64^{\prime} \mathrm{E}\right.$; water depth, $\left.1697.2 \mathrm{~m}\right)$ lies on a basement high that is part of a tilted block formed at the $77^{\circ} \mathrm{E}$ Graben. This block is bounded $7 \mathrm{~km}$ eastward from Site 747 by three normal faults that form the western limit of the $77^{\circ} \mathrm{E}$ Graben. The main drilling results at Site 747 , related to the tectonic and stratigraphic history of this part of the CKP (Fig. 3), are summarized below (Aubry and Berggren, 1989; Shipboard Scientific Party, 1989a).

The recovered basement rocks consist of up to 12 lava flows separated by brecciated basalt (Unit V). The flows were emplaced on a near-horizontal surface and in a subaerial environment. Basalt flows are dated at $110 \mathrm{Ma}$ (Whitechurch et al., this volume). Their composition is intermediate between typical mid-ocean ridge basalts and normal oceanicisland type basalts.

Marine pelagic sedimentation, mainly with nannofossil chalk, accumulated on the subsiding basement from late Cenomanian-early Turonian through middle Maestrichtian (71.6 Ma) time (Unit IV). During Campanian-Maestrichtian 


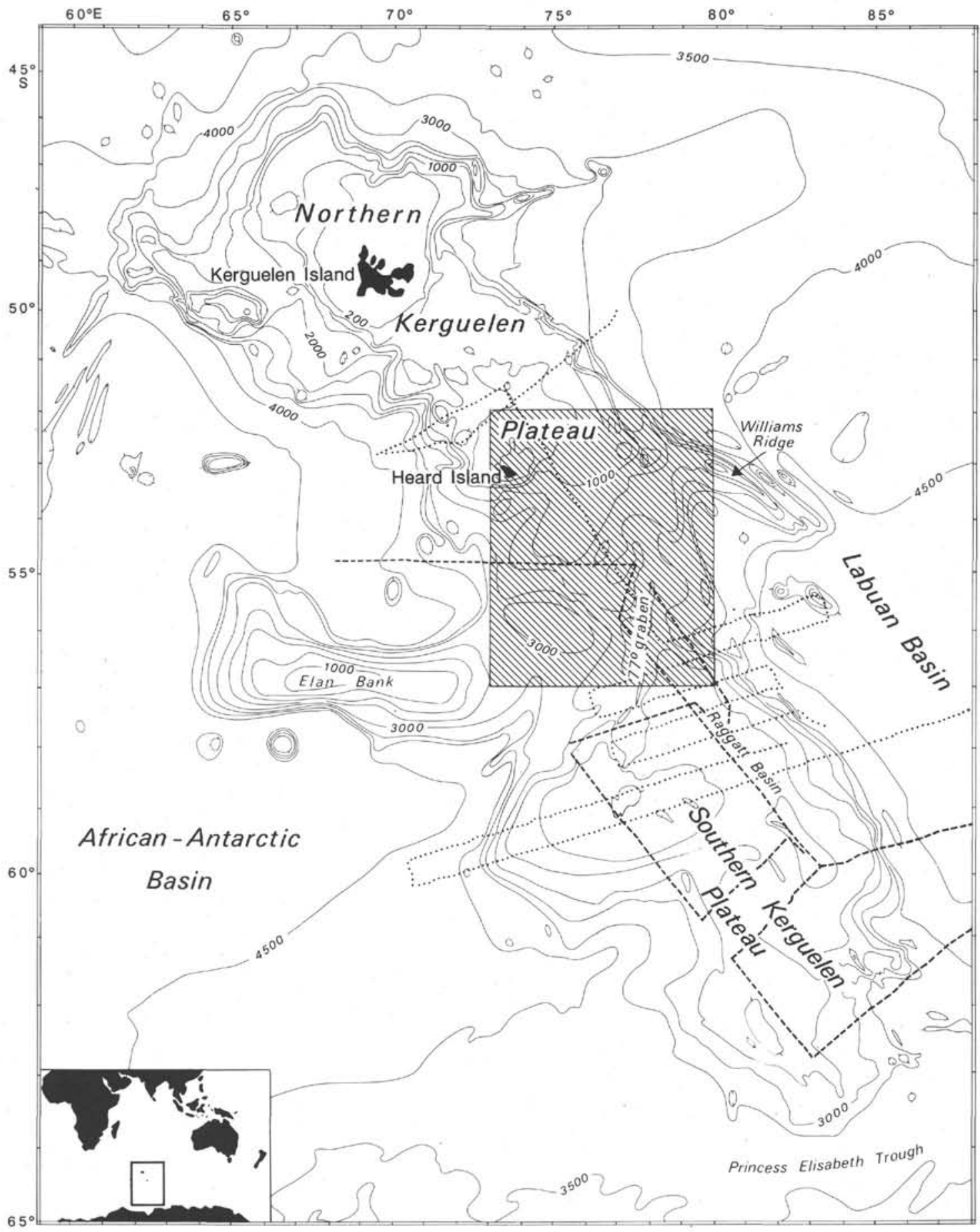

Figure 1. Location and bathymetric map (in meters) of the Kerguelen Plateau (after Schlich et al., 1987). Also shown are the locations of the multichannel seismic surveys from the French Marion Dufresne Cruise MD 47 (dashed lines) and Australian Rig Seismic Cruise RS 02 (dotted lines) used in this work. The study area is shaded.

time, the basement subsided at a rate of $15-25 \mathrm{~m} / \mathrm{m} . \mathrm{y}$. and sedimentation rates were high $(20 \mathrm{~m} / \mathrm{m} . \mathrm{y}$.).

Between middle Maestrichtian (71.6 Ma) and earliest Danian (66 Ma) time, a major tectonic episode resulted in the uplift, tilting, and erosion of the basement near Site 747 (Unit III).

Rapid subsidence from about $200-500$ to $2000 \mathrm{~m}$ at a rate of about $600-800 \mathrm{~m} / \mathrm{m}$.y. was underway by early Danian time.
During the Paleocene between 66 and $63.8 \mathrm{Ma}$, the sedimentation rate was very slow $(2-5 \mathrm{~m} / \mathrm{m} . \mathrm{y}$.), and the sediments consist of nannofossil chalks with basaltic cobbles and volcanogenic sands and pebbles, indicating the proximity of an emerged feature (Subunit IIC).

A second hiatus, during the Paleocene between 63.8 and 58 $\mathrm{Ma}$, could be related to an uplift of about $500 \mathrm{~m}$. 


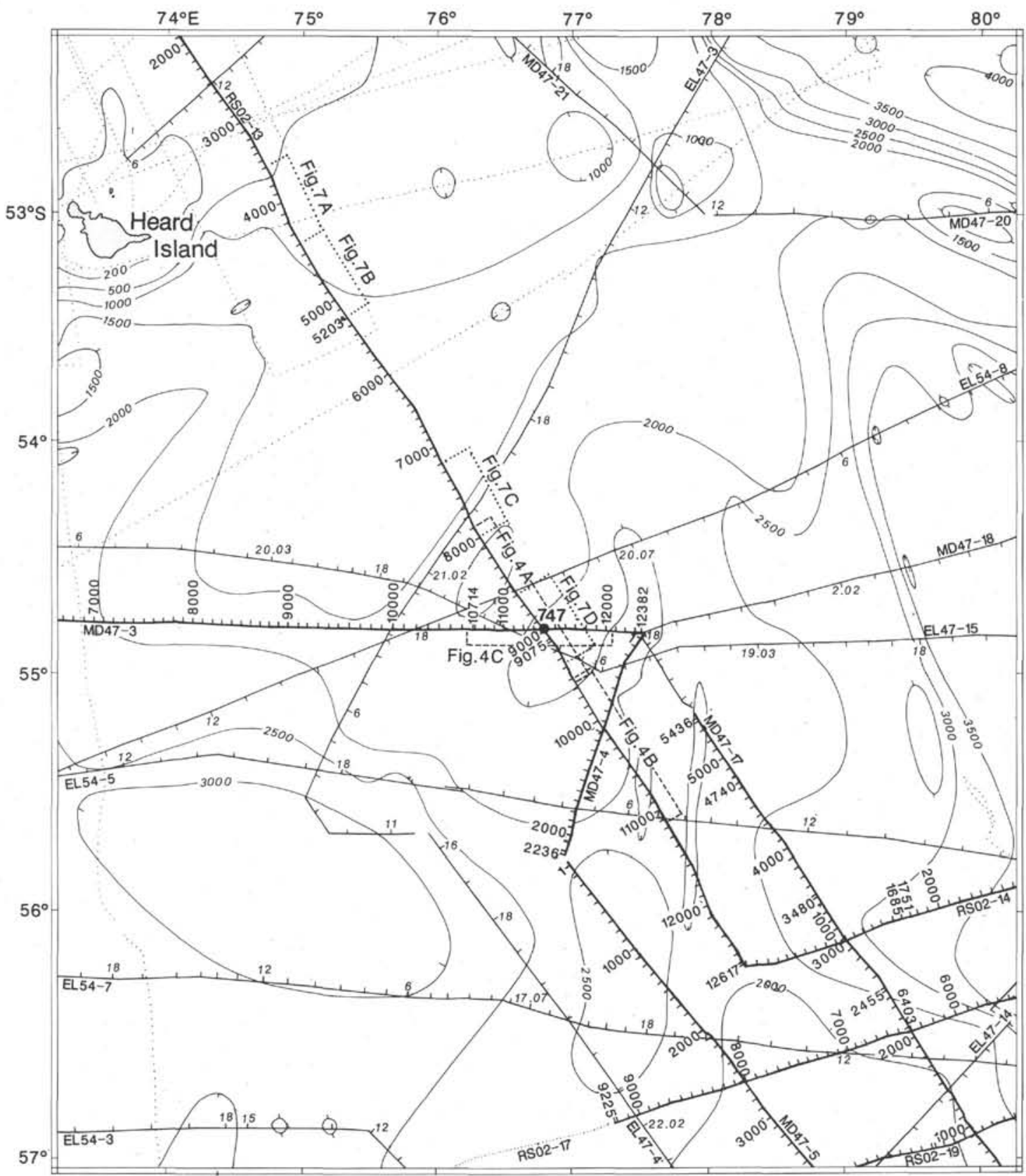

Figure 2. Track chart and bathymetry (in meters) of the study area. Lines denote single-channel seismic profiles and heavy lines denote Rig Seismic and Marion Dufresne multichannel seismic profiles. Seismic profiles shown in this work are identified along the tracks by their corresponding figure number.

In the early Eocene, between 58 and $52.6 \mathrm{Ma}$, pelagic nannofossil chalk was deposited at a very slow rate of 0.4 $\mathrm{m} / \mathrm{m}$.y. (Subunit IIB).

The longest hiatus occurred between the early Eocene $(52.6 \mathrm{Ma})$ and the late Eocene $(37.8 \mathrm{Ma})$, during which time the site subsided about $500 \mathrm{~m}$.

Since the late Eocene $(37.8 \mathrm{Ma})$, sedimentation was continuous at a low rate of about $5 \mathrm{~m} / \mathrm{m}$.y., except for a hiatus of about 2.5 m.y. duration at the Miocene/Pliocene boundary. Sediments predominantly consist of pelagic carbonates, changing to mainly biosiliceous oozes during the Pliocene/ Pleistocene in response to the deterioration of late Cenozoic climates (Subunits IIB and IIA and Unit I).

\section{BASEMENT OF THE CENTRAL KERGUELEN PLATEAU}

The basement of the Kerguelen Plateau in general, and of the SKP in particular, was studied by Schaming and Rotstein (1990) and Rotstein et al. (1990). Two types of basement were identified from the seismic records: nonreflective acoustic basement with poor internal reflections and reflective layered basement with clear internal reflections. Nonreflective acoustic basement is mostly associated with elevated basement ridges and acoustic layered basement with volcanic lava flows. The basement ridges appear to have been elevated volcanoes that served as the sources for the volcanism for the 


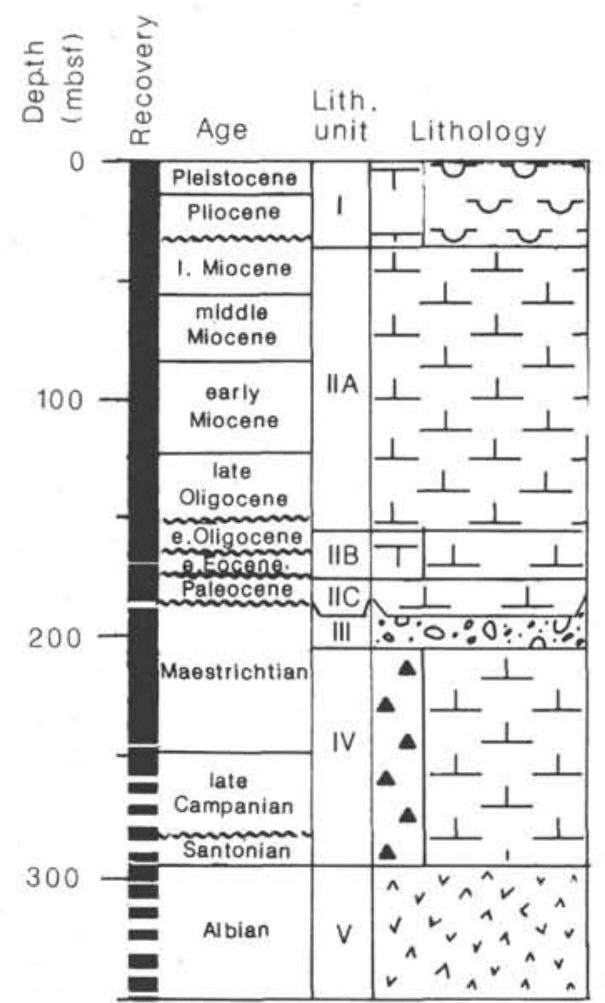

Figure 3. Stratigraphic column at Site 747 showing recovery, ages, lithologic units, and lithologies (Shipboard Scientific Party, 1989a).

adjacent parts of the plateau. Rotstein et al. (1990) also suggested that the typical volcanic morphology was eroded from the SKP, leaving this large area without apparent volcanic sources as in the NKP.

Figure 4 shows the two types of basement on two MCS profiles. Nonreflective acoustic basement is observed on Profile RS 02-13 from shotpoints 9400 to 9600 and from 10400 to 10600 . In places, diffraction hyperbolae appear within the nonreflective acoustic basement, which indicate the presence of heterogeneities with dimensions from several meters to 10 $\mathrm{m}$. On Profile MD 47-03, the limit of the nonreflective acoustic basement is well delineated by normal faults at shotpoints 11200 and 11360 .

Reflective layered basement consists of low-amplitude, high-continuity reflectors that are generally subparallel (Fig. 4). The length of the reflectors is commonly more than 10-20 $\mathrm{km}$. Using a basement velocity of $5-6 \mathrm{~km} / \mathrm{s}(\mathrm{Li}, 1988$; Schaming and Rotstein, 1990), the spacing between the reflectors is about $100-200 \mathrm{~m}$. Although drilling at Site 747 penetrated only $54 \mathrm{~m}$ of basement (Shipboard Scientific Party, 1989a), the results suggest that the reflectors can be associated with a series of volcanic flows emplaced in a shallow-water to subaerial environment. Because the thickness of each cored lava flow is $<10 \mathrm{~m}$, we suggest that the reflectors of the reflettive layered basement result from variations in the gradation between massive lava flows and brecciated basalt. This hypothesis is also based on ODP results obtained on the Vøring plateau (Norwegian continental margin) at Site 642 (Eldholm et al., 1987). At this site, the MCS section shows a 760 -m-thick sequence of layered basement with a spacing between the reflectors of about $100 \mathrm{~m}$. The entire sequence was drilled and consists of 120 flows, each several meters thick. Eldholm et al. (1987) have shown that the individual flows are not sufficiently thick to give rise to the observed reflectors; they have grouped the flows using variations in the physical properties, and their calculations indicate that the transitions between the groups often produce reflection coefficients of a magnitude sufficient to explain the reflection events observed in the seismic record.

The two types of basement have been mapped, when we have observed them on the MCS data. Because of sparse MCS data and because these features were not observed on SCS profiles, it is not easy to study their geographical extent. However, using all the available MCS data, we propose the distribution pattern shown on Figure 5. The reflective layered basement (lava flows) occupies a very large area compared with the nonreflective acoustic basement (basement ridges). The apparent dip of the lava flows along the profiles varies from subhorizontal to about $10^{\circ}$, and generally the dip of the lava flows decreases toward the basement ridges. The true dip and direction of the lava flows can only be computed close to two MCS profile intersections (MD 47-03 with RS 02-13 and MD 47-04 with RS 02-13); at these two points the real dip is about $10^{\circ}$ in a northwest direction (Fig. 5). Unfortunately, these values are only rough estimates for two reasons: (1) small basement ridges were observed close to the two intersection points and, thus, obscured identification of the dipping reflectors; and (2) because basement was faulted and tilted at the end of the late Maestrichtian, the computed dip values do not necessarily correspond to the initial dips. Basement ridges occupy small areas, and there is insufficient MCS data to check if they correspond to isolated or lineated features. At the intersection of Profiles MD 47-04 and RS 02-13, several basement ridges were observed on the two profiles; thus, it is possible that the basement ridges are elongated in an east-west direction, as suggested by the hachured line in Figure 5.

\section{TECTONIC SETTING}

The most striking features on the MCS data from the CKP are normal faults with throws exceeding $1 \mathrm{~km}$, assuming a velocity of $2.0 \mathrm{~km} / \mathrm{s}$ in the sediments (Fig. 4, Profile RS 02-13, shotpoint 10500 and Profile MD 47-03, shotpoint 11600). First identified by Houtz et al. (1977), the faults were interpreted to belong to two prominent north-oriented grabens referred to as the $75^{\circ} \mathrm{E}$ and $77^{\circ} \mathrm{E}$ grabens. Rotstein et al. (1991) have studied tectonic features in the Labuan Basin situated to the east and southeast of the CKP, and they have documented that the numerous normal faults observed in the Labuan Basin and along the eastern part of the SKP delineate tilted blocks 30-40 $\mathrm{km}$ wide. The distribution of the tilted blocks is apparently associated with two large uplifts. One uplift is centered on the eastern part of the SKP and extends into the Labuan Basin; the western half of the other uplift occupies the eastern part of the Labuan Basin. The trend of these two uplifts is parallel to the eastern flank of the SKP (about N140 ${ }^{\circ}$ ). Rotstein et al. (1991) associate the two uplifts with a major extensional tectonic event that occurred between 75 and $68 \mathrm{Ma}$.

The three normal faults, $7 \mathrm{~km}$ to the east of Site 747 (Fig. 4, Profile MD 47-03, shotpoint 11500), have a composite throw of about $1 \mathrm{~km}$ and delineate two tilted blocks. This fault system may be correlated with faults observed on two adjacent SCS profiles (EL 47-15 and EL 54-08) and on MCS Profile RS 02-13 (shotpoint 9400). Thus, its trend can be delineated (Fig. 5): the general direction is north-south with a pronounced arc pointing toward the east. To the south, on MCS Profile RS 02-13 (Fig. 4, shotpoint 9400), the throw of the fault system drastically diminishes. No seismic data is available to define the northern limit of this fault system. Thus, the fault system has a north-south extent of at least 90 $\mathrm{km}$. Similar faults with smaller throws $(<200 \mathrm{~m})$ were observed to the east and to the west of Site 747 on MCS Profile 
MD 47-03 (Fig. 4, shotpoints 10700 to 11900 ) with a dip toward the east and the corresponding tilted blocks downthrown to the west.

The normal faults and tilted blocks belong to a system that may be analogous to the half-graben models proposed by Rosendahl (1987). Following Rosendahl (1987), we have tried to describe the tectonic features observed on the CKP in terms of ideal half-grabens: the fault system is identified as a border fault system (BFS) and is distinguished from the other faults (Figs. 5 and 6B). Toward the east, the end of the half-graben is defined by the block observed after the last normal fault facing the east; toward the west, its end is defined in the same manner, after the last normal fault facing the west. The half-graben has an east-west maximum extent of about 60 $\mathrm{km}$.

All SCS and MCS data on the CKP show the same tectonic morphology. Figure 5 presents the structural interpretation in terms of half-grabens, and Figure 6 shows four line drawings of SCS or MCS profiles crossing the CKP. We observed 10 half-grabens, numbered HG1 to HG10, within the CKP. The half-graben described previously, close to Site 747, is HG5; to the east of this half-graben, another half-graben (HG6) was observed. The normal faults of HG6 are facing the west and the BFS is less pronounced (Fig. 6B). These two half-grabens form Rift Unit RU3, as described by Rosendahl (1987). Rift Unit RU3 has a north-south length of at least $120 \mathrm{~km}$ and a width, between the two facing BFS, of about $60 \mathrm{~km}$. Rift Unit RU3 is followed to the south by RU4, which is defined by two symmetric half-grabens, HG7 and HG8, as shown on Figures 5 and $6 \mathrm{D}$. However, the limit between the two half-grabens is not symmetric compared with the BFSs but, rather, shifted toward the east. Close to the southern limit of the tectonic map, the northern part of southernmost Rift Unit RU5 was observed. To the west of RU3, Rift Unit RU2 is a quite different tectonic unit: the faults and the BFS have a smaller dip and their direction is north-south without any arc. At $53^{\circ} \mathrm{S}$ and $77^{\circ} \mathrm{E}$, a very large rift unit (RU1; Fig. 5) was found that is expressed by a BFS with vertical throws of up to $2 \mathrm{~km}$ (Fig. $6 B)$. Between RU1 and RU3, the lack of seismic data preclude identification of the rift limits. However, because the rift units described in this paper seem to have apparently the same dimensions, we suggest that a distinct rift unit should exist between RU1 and RU3.

The tectonic style described here, including border fault systems, half-grabens, and rift units, shows similarities with the architecture of the East African continental rift system (Rosendahl, 1987), the North Viking graben in the North Sea (Badley et al., 1988; Scott and Rosendahl, 1989), and the Suez Rift (Colleta et al., 1988). In this sense, Rift Units RU1-RU5 form a rift zone that corresponds to the northern half of the so-called $77^{\circ} \mathrm{E}$ Graben.

Results at Site 747 (Shipboard Scientific Party, 1989a) partially constrain the age of the $77^{\circ} \mathrm{E}$ Graben. A major episode of uplift is described between middle Maestrichtian $(71.6 \mathrm{Ma})$ and earliest Danian $(66 \mathrm{Ma})$ times, followed by rapid subsidence in early Danian times at a rate of $600-800 \mathrm{~m} / \mathrm{m}$.y. from 50-200 to $2000 \mathrm{~m}$ (Aubry and Berggren, 1989). This tectonic episode appears to correspond to the formation of half-graben HG5. Results at Site 748 (Shipboard Scientific Party, 1989b) located $400 \mathrm{~km}$ to the south of Site 747 , show that a tectonic uplift occurred between the late Maestrichtian and the late Paleocene $(63.8 \mathrm{Ma})$, followed by a rapid subsidence at a rate of about $150 \mathrm{~m} / \mathrm{m}$.y. from $50-200$ to $1000 \mathrm{~m}$. Thus, the entire $77^{\circ} \mathrm{E}$ Graben certainly formed at $72 \mathrm{Ma}$. At Site 747, two other tectonic episodes (a slight uplift of about $500 \mathrm{~m}$ between 63.8 and $58 \mathrm{Ma}$ and the subsidence of about $500 \mathrm{~m}$ between 52.6 and $37.8 \mathrm{Ma}$ ) can be related to movements along the pre-existing faults that formed the $77^{\circ} \mathrm{E}$ Graben. However, as observed on the seismic sections, the main phase of activity of the $77^{\circ} \mathrm{E}$ Graben occurred during the late Maestrichtian.

\section{SEISMIC STRATIGRAPHY}

We interpreted MCS sections after the method of Vail et al. (1977). Unfortunately, the lack of MCS profiles compared to the variability of stratigraphic units precludes a detailed study, and SCS profiles are not suitable for such an analysis. We present here the results of the seismic stratigraphic interpretation of MCS Profile RS 02-13 between Heard Island and Site 747 (Fig. 2).

MCS Profile RS 02-13 extends for $290 \mathrm{~km}$ between Heard Platform (shotpoint 3200) and Site 747 (shotpoint 8990). Along this part of the profile, the sediment thickness changes from $<0.3 \mathrm{~s}$ two-way traveltime (twt) on Heard Platform to a maximum of 1.5 -s twt at shotpoint 4000 (Fig. 7A), and is 0.35 -s twt at Site 747 (Fig. 7D). The zone of maximum sediment thickness also corresponds to the base of the slope from the Heard Platform. In this zone (Fig. 7A), eight seismic sequences were defined based upon recognition of surfaces of discontinuity from reflection terminations. All the seismic sequences thin toward the south, and only two of them are more than 0.1-s twt thick at Site 747 (Fig. 7D).

The correlation between seismic reflectors and lithologies at Site 747 has been discussed by Shipboard Scientific Party (1989a) and Fritsch et al. (this volume). In the description of the seismic sequences given below, we will use the results of these correlations. Moreover, Fritsch et al. (this volume) have used, for the description of the seismic sequences close to Site 747 , the nomenclature proposed by Coffin et al. (1990) for the Raggatt Basin; the same definition will be used to describe the eight seismic sequences identified on MCS Profile RS 02-13.

Sequence K3 of Coffin et al. (1990) is found at Site 747 from 190 to 295 mbsf (Unit IV and III; Shipboard Scientific Party, 1989a) and, below, a upper Cenomanian-lower Turonian 2-m-thick layer of bioclast grainstone with glauconite overlies the basement. The top of the lowest seismic sequence defined on Profile RS 02-13 clearly corresponds to the top of Sequence $\mathrm{K} 3$, but the age of the deepest reflectors is not well established. Because the sequence thickens toward the northwest, reaching a maximum thickness of $0.3-\mathrm{s} \mathrm{twt} \mathrm{(Fig.} \mathrm{7C,} \mathrm{shotpoint}$ 7500) without clear unconformity, we simply named this sequence " $\mathrm{K}$ ". Sequence $\mathrm{K}$ is characterized by high-continuity, moderate-amplitude reflectors, and it onlaps the basement relief. Before deposition of Sequence $\mathrm{K}$, the basement was strongly eroded. This large erosion occurred after the emplacement of the last volcanic flow $(110 \mathrm{Ma}$; Whitechurch et al., this volume) and before the deposition of the oldest part of Sequence K (upper Cenomanian-lower Turonian; Shipboard Scientific Party, 1989a). However, this last age represents a minimum because the oldest sediments of Sequence $\mathrm{K}$ were not deposited at Site 747. If we extend the oldest reflector of Sequence $\mathrm{K}$ at Site 747 toward the north, we find that Sequence $\mathrm{K}$ thickens at the bottom by about $200 \mathrm{~m}$ (shotpoint 7000 of MCS Profile RS 02-13).

At Site 747, Sequence P1 of Coffin et al. (1990) is represented by a thickness of $65 \mathrm{~m}$ (125 to $190 \mathrm{mbsf})$ or $76-\mathrm{ms}$ twt (Subunits IIC and IIB, and lower part of Subunit IIA). Sequence P (Sequences P1 and P2) was clearly observed between shotpoints 7600 and 8700 (Figs. 7C and 7D), but it remains very thin in this zone $(<150 \mathrm{~m})$. From shotpoint 7600 and northward, we can distinguish Sequences P1 and P2 (Figs. 7B and 7C). These two sequences have the same seismic character (high-continuity, high-amplitude reflectors) and are 
A

NW

RS $02-13$

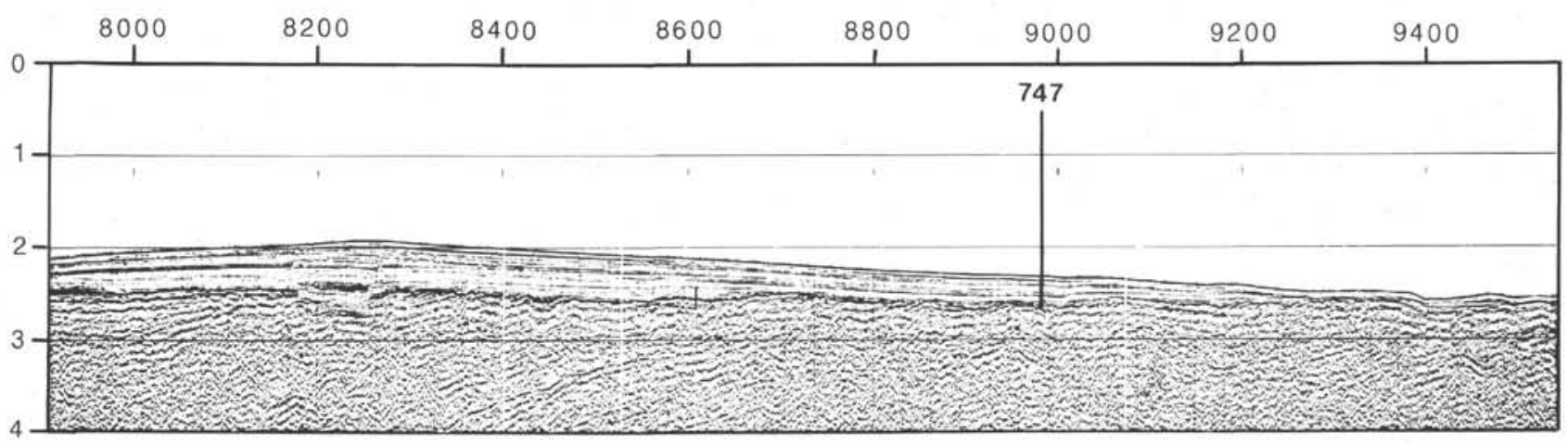

NW

RS $02-13$

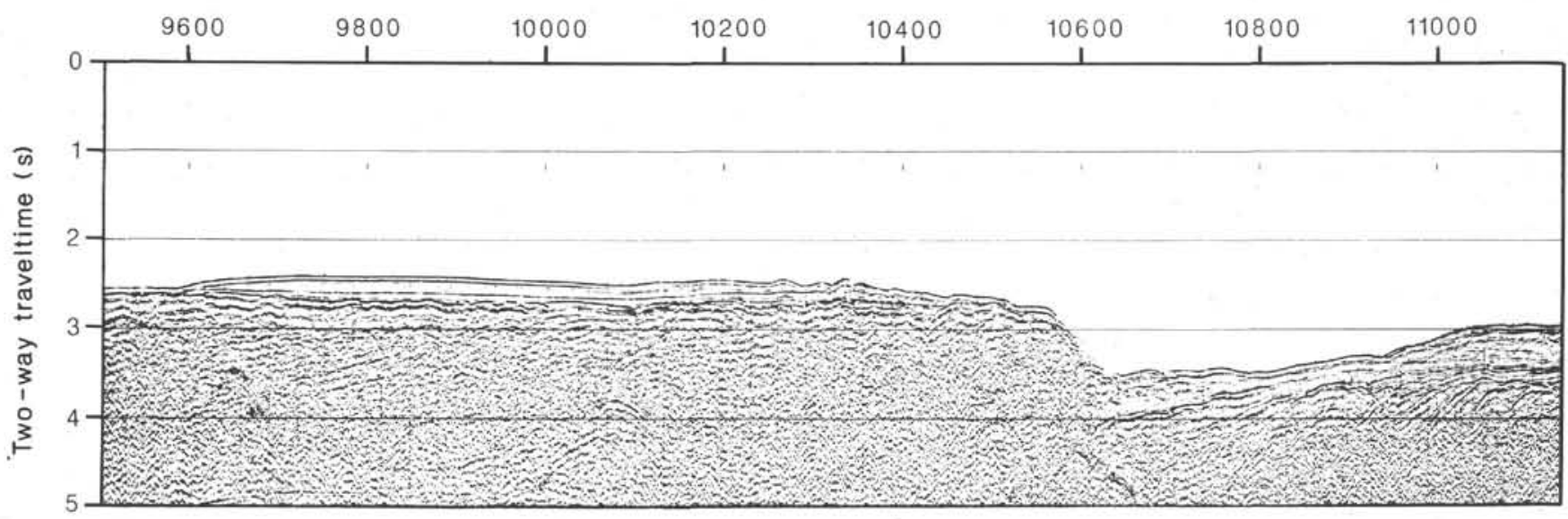

W

MD $47-03$

$E$

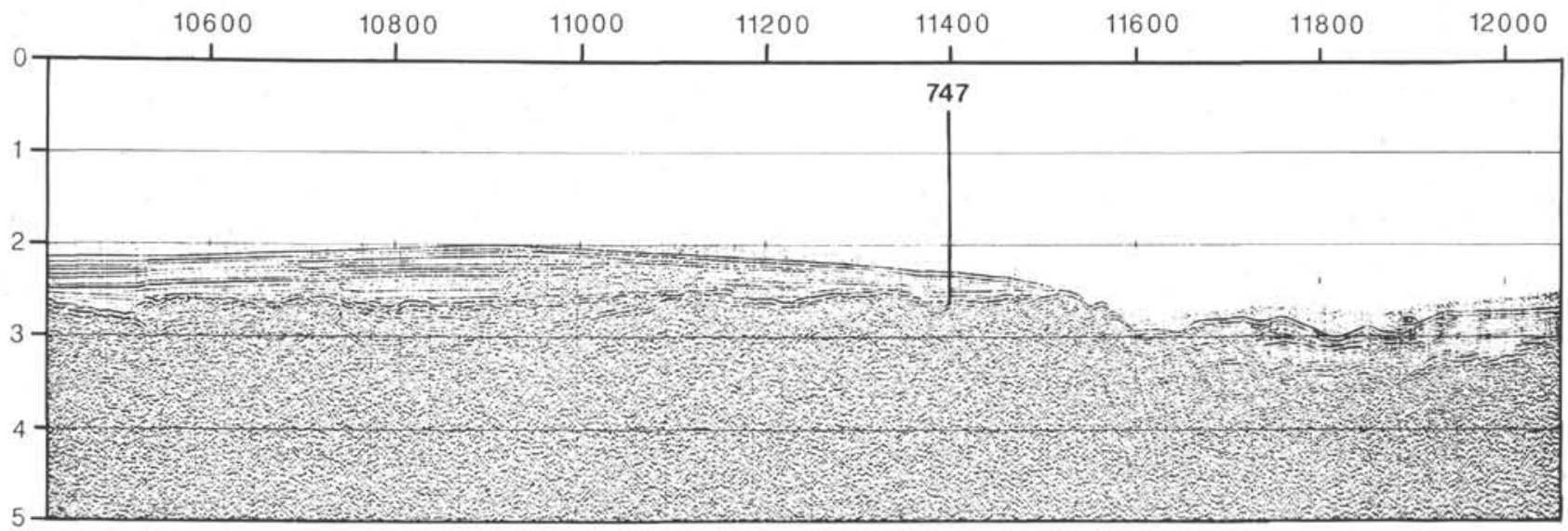

$10 \mathrm{~km}$

Figure 4. Uninterpreted (A) and interpreted (B) multichannel seismic sections RS 02-13 and MD 47-03 showing the basement ridges (BR) and the basement reflectors. The location of the sections is given in Figure 2. 

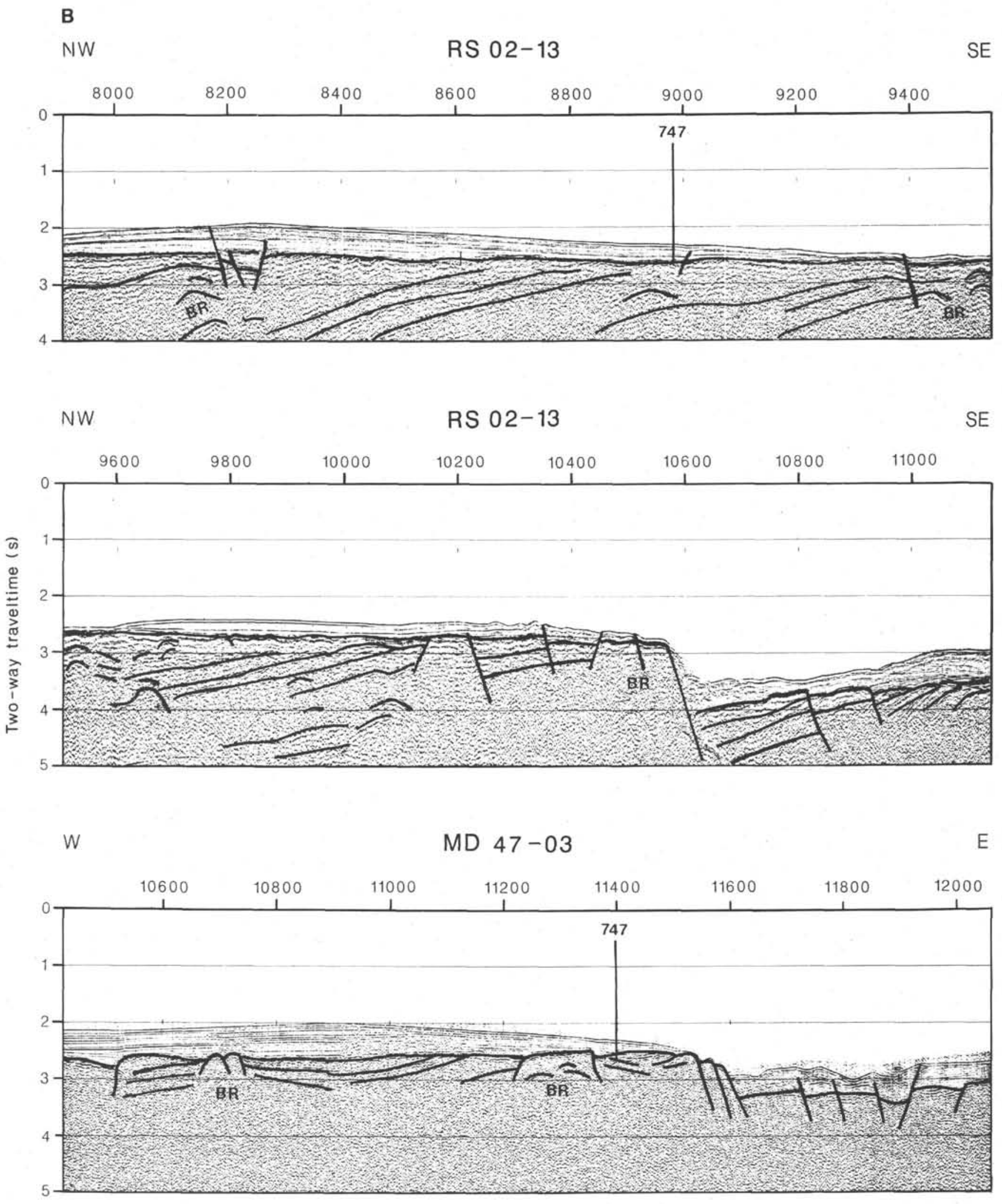

$E$

Figure 4 (continued). 


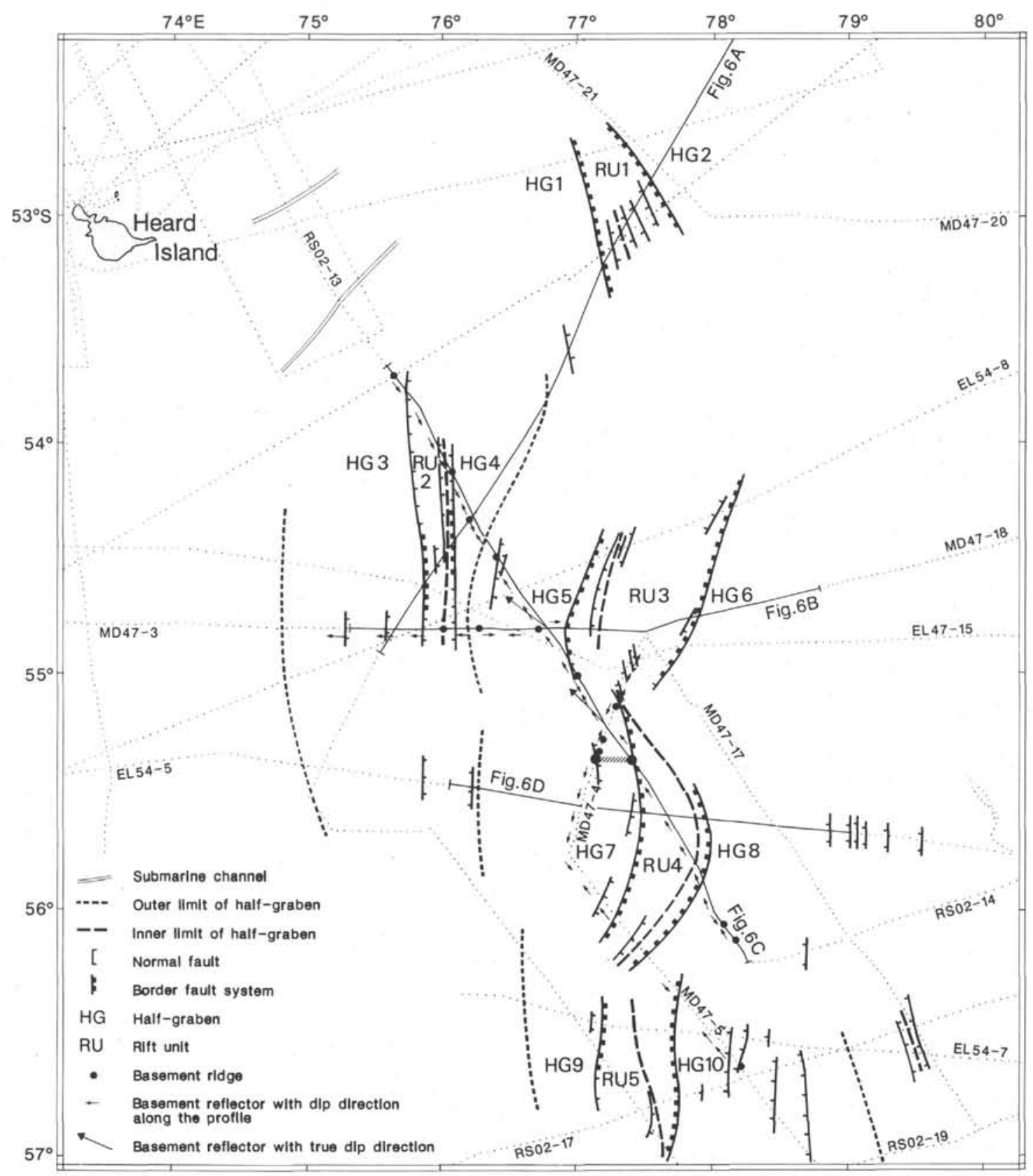

Figure 5. Morphostructural map of the Central Kerguelen Plateau.

separated by an unconformity that is identified by toplaps at the top of Sequence P1.

The main unconformity observed on MCS Profile RS 02-13 corresponds to a high-amplitude reflector also defined by toplaps at the top of Sequence P2. This unconformity, clearly observed at Site 747, represents the longest hiatus of the sediment section, lasting from the early Eocene $(52.6 \mathrm{Ma})$ to the late Eocene $(37.8 \mathrm{Ma})$.

Sequences PN1 (upper part of Subunit IIA) and NQ1 (Unit I) of Coffin et al. (1990) are characterized by high-continuity, high-amplitude reflectors. They are separated by a minor unconformity that corresponds, at Site 747, to a hiatus of 2.2 $\mathrm{Ma}$ (7.2-5.0 Ma), and on MCS Profile RS 02-13 to toplaps of PN1 (Figs. 7C and 7D). This unconformity, clearly observed in the entire Raggatt Basin (Coffin et al., 1990), seems to represent the first occurrence of the large event that is still eroding the seismic sequences of the Raggatt Basin and the CKP.

Close to Heard Island (Fig. 7A and 7B), Sequences PN1 and NQ1 thicken, and three other local sequences can be identified. Because the unconformity remains at the top of Sequence PN1, we have named these three sequences "Q1" (above NQ1), "N2"' and "N1"' (between NQ1 and PN1). The five sequences (PN1 to Q1) have a maximum thickness of about $800 \mathrm{~m}$ at shotpoint 4000 (Fig. 7A). As the sequences below Sequence PN1 do not vary significantly in thickness, we propose that the main unconformity (between 52.6 and 37.8 Ma at Site 747) marks the formation of the relief observed to the north of Figure 7A (i.e., the northern limit of the CKP against the basement of the Heard Island volcanic complex).

A large submarine channel was observed on the bathymetric data close to MCS Profile RS 02-13 (Fig. 7B, shotpoint 

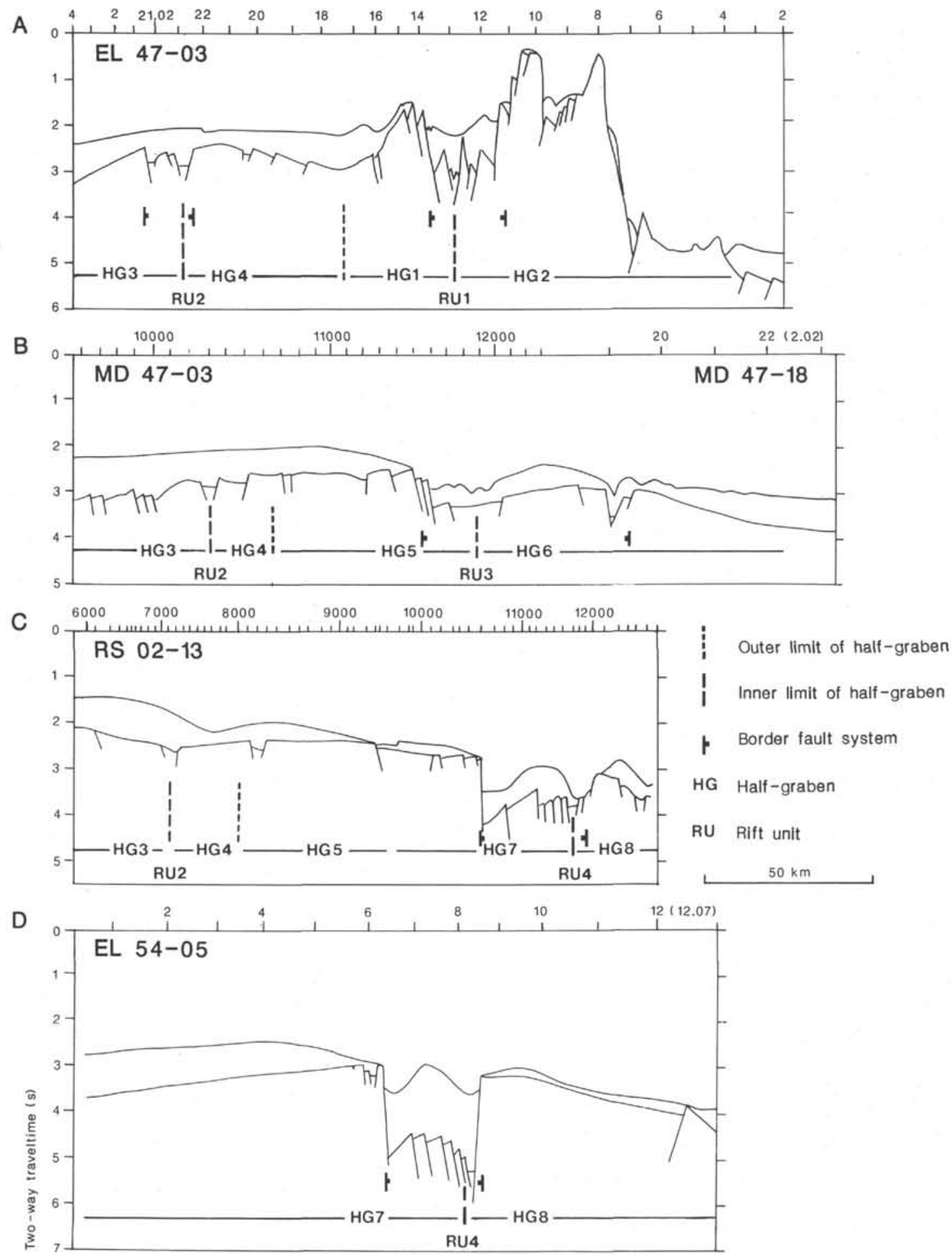

Figure 6. Line drawings of four seismic profiles projected in an east-west direction. The location of the corresponding seismic sections is given in Figure 5.

4950): its orientation is northeast-southwest at almost a right angle to Profile RS 02-13 (Fig. 5). The submarine channel, or canyon, is bereft of sediment infill. It is still active and corresponds to an area of nondeposition and/or erosion for Sequences N1 to Q1. On both sides of the channel, between shotpoints 4200 and 5200 (Fig. 7A and 7B), the five distinct seismic Sequences PN1 to Q1 represent the different phases of formation of the fan associated with the submarine channel.

From shotpoint 3600 to 4400 (Fig. 7A), the seismic facies of each sequence is directly linked to the slope and to the energy of deposition: Sequence PN1 consists of chaotic reflectors, resulting from a high-energy deposition; the reflectors of 
NW

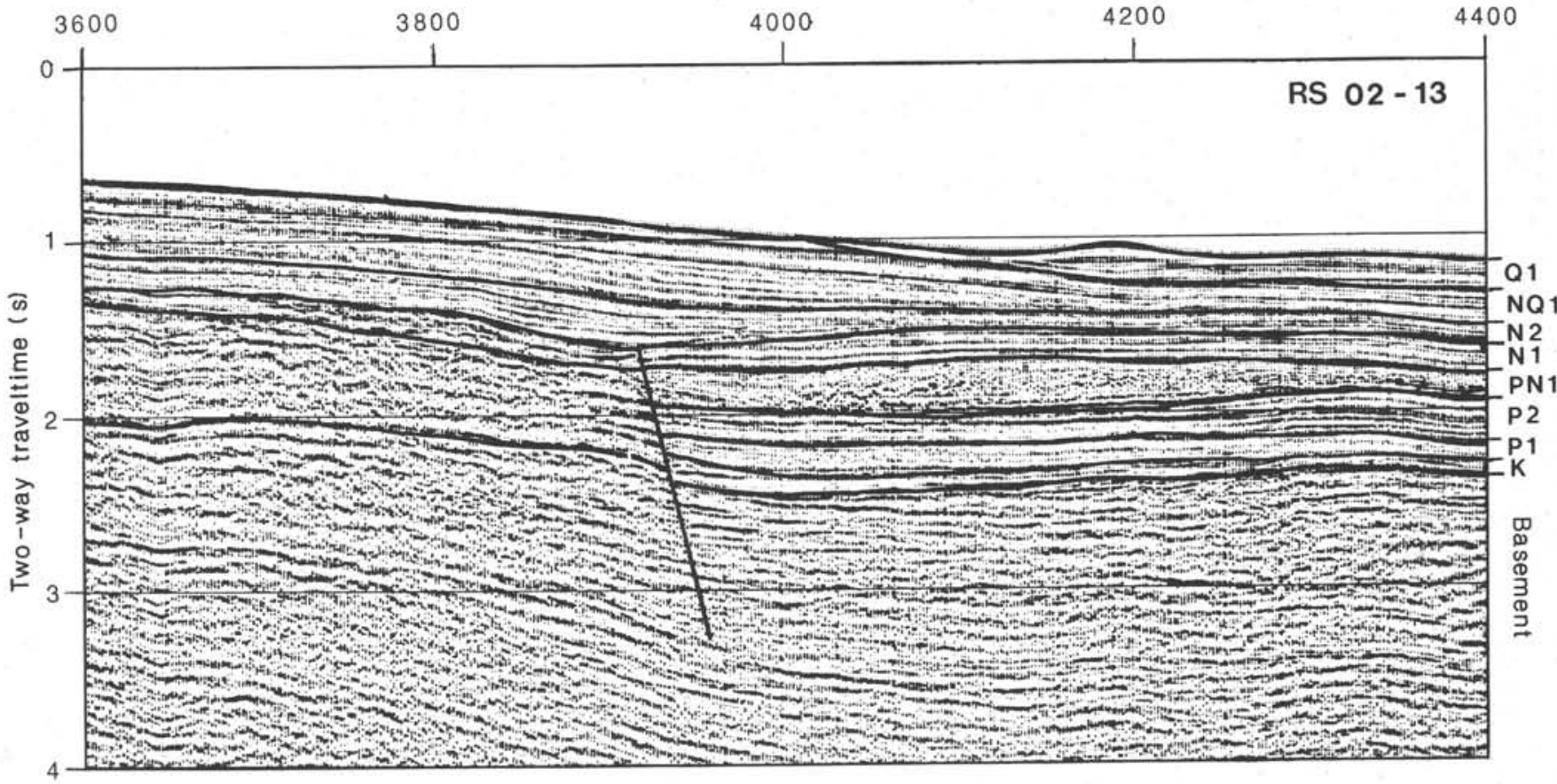

$10 \mathrm{~km}$

NW

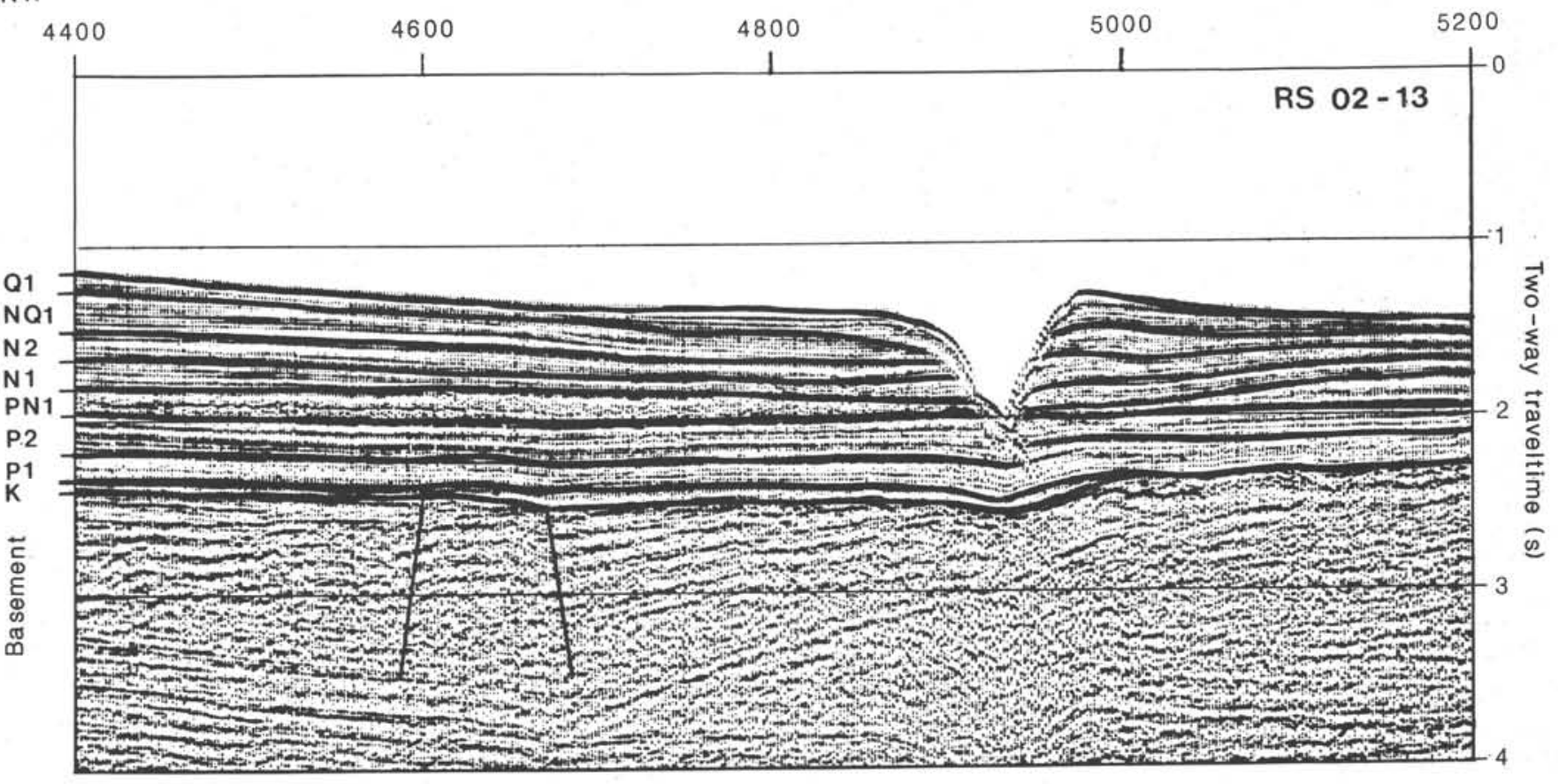

$10 \mathrm{~km}$

Figure 7. Multichannel seismic sections RS 02-13 showing the seismic sequences identified. The location of the sections is given in Figure 2. 
NW

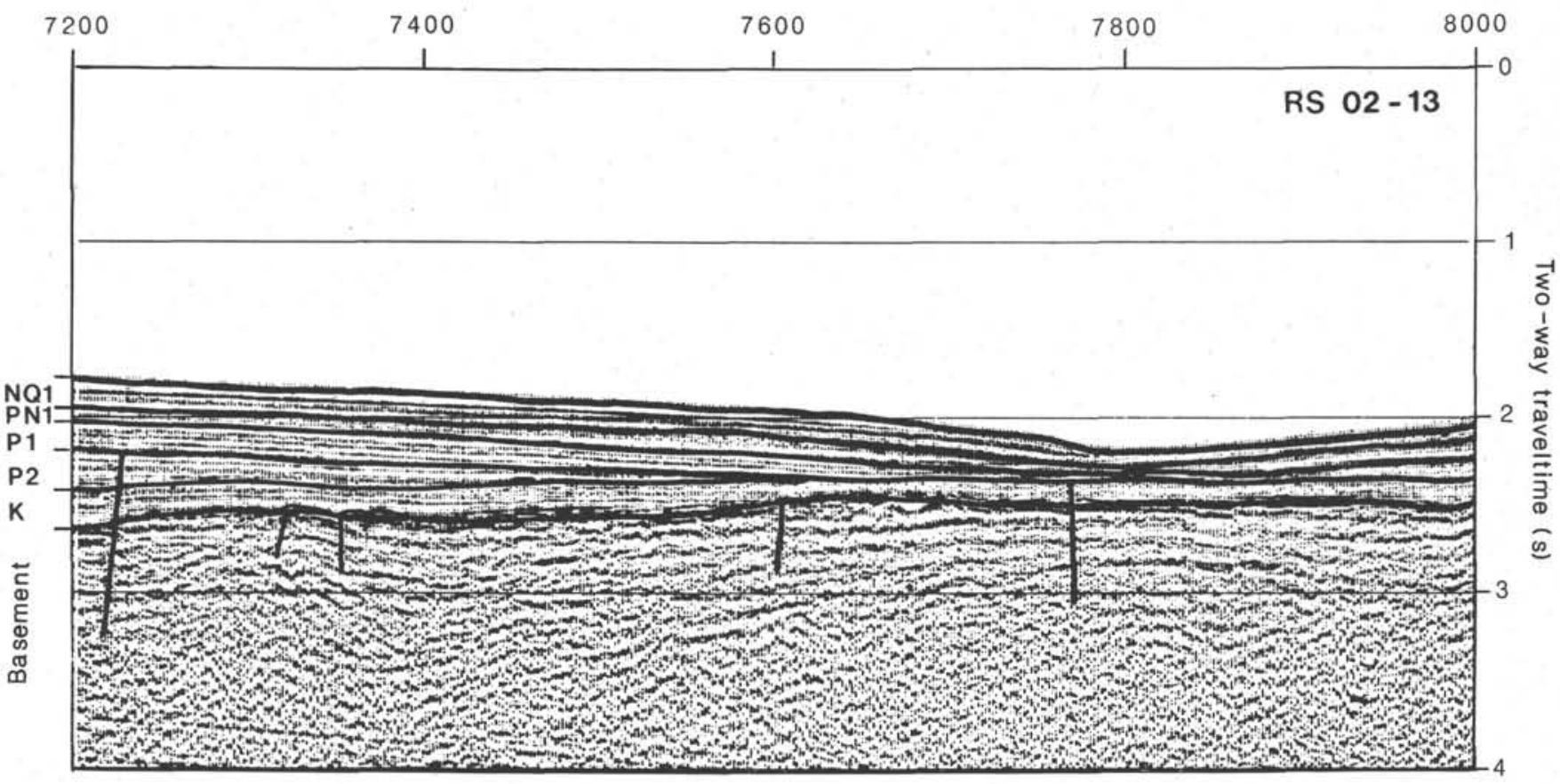

NW

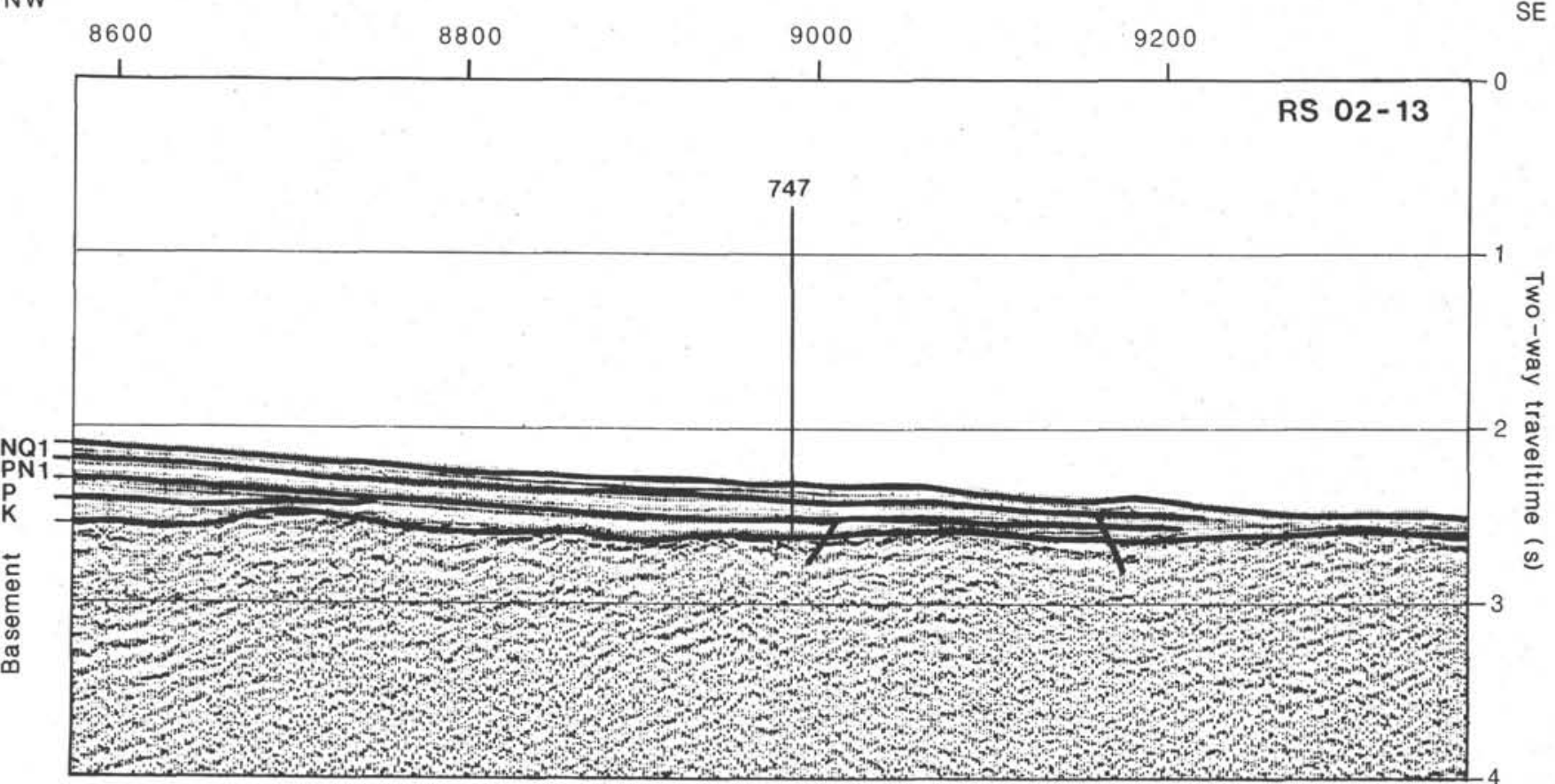

Figure 7 (continued). 
Sequences N1, N2, and NQ1 have a high amplitude and are parallel to sigmoidal, which indicates low sediment supply and rapid subsidence; Sequence Q1 is only observed between shotpoints 4000 and 5200 and is the result of a very low sediment supply linked to the still active erosional event.

\section{EVOLUTION OF THE CENTRAL KERGUELEN PLATEAU}

The opening between Antarctica-Australia and India was initiated at approximately $130 \mathrm{Ma}$, and seafloor spreading resulted in about $500-\mathrm{km}$ separation between the two continents at $110 \mathrm{Ma}$ (Norton and Sclater, 1979; Powell et al., 1988). At that time, the CKP was formed and resulted from an excessive magmatism linked to a mantle plume at or near the spreading center (Whitechurch et al., this volume). Moreover, the direction observed for the spreading ridge that separated Antarctica-Australia from India is about N70 (Powell et al., 1988); this direction is similar to the direction observed for the basement ridge on the CKP and at a right angle to the measured direction of the basalt flows (Fig. 5). The NKP (Munschy and Schlich, 1987) and the SKP (Coffin et al., 1990) were formed at about the same time. Thus, the Kerguelen Plateau appears to have been emplaced during a very short period of time $(<10 \mathrm{Ma})$. Most of the volcanic activity was probably subaerial at the end of the plateau construction.

After $110 \mathrm{Ma}$ and before upper Cenomanian-lower Turonian, erosion of the basement occurred. From upper Cenomanian-lower Turonian to $71.6 \mathrm{Ma}$, the basement subsided at a rate of about $15-25 \mathrm{~m} / \mathrm{m} . \mathrm{y}$., and shallow-water glauconitic calcarenites followed by late Campanian to Maestrichtian chalks were deposited with a sedimentation rate of about 20 $\mathrm{m} / \mathrm{m}$. $\mathrm{y}$. The shape of Sequence $\mathrm{K}$ indicates that the subsidence is not uniform: the subsidence rate was low (15-25 $\mathrm{m} / \mathrm{m} . \mathrm{y}$.) close to the basement ridges; elsewhere it reached a value of about $50 \mathrm{~m} / \mathrm{m}$.y.

At $72 \mathrm{Ma}$, a major tectonic episode stretched the oceanic basement of the CKP in an east-west direction. Ten halfgrabens appeared on the CKP and formed five approximately symmetric rift units. These rift units correspond to the northern part of the $77^{\circ} \mathrm{E}$ Graben system that extends, to the south, into the SKP. Vertical movements, from 71.6 to $66 \mathrm{Ma}$, are significant: uplift of about $500 \mathrm{~m}$ was followed by subsidence from the sea level to about $2000 \mathrm{~m}$ at a rate of $600-800 \mathrm{~m} / \mathrm{m} . y$. at Site 747.

From 66 to $63.8 \mathrm{Ma}$ and from 58 to $52.6 \mathrm{Ma}$, sedimentation was continuous at a low rate; a hiatus exists from 63.8 to 58 $\mathrm{Ma}$. The low sedimentation rate and hiatus were probably caused by recurrent faulting along the $77^{\circ} \mathrm{E}$ Graben. The hiatus represents $5.8 \mathrm{Ma}$ close to the top of the tilted block at Site 747; however, away from the zones of uplift, sedimentation could have been continuous over the interval.

The major hiatus between 52.6 and $37.8 \mathrm{Ma}$ at Site 747 is also probably related to a recurrent faulting episode along the $77^{\circ} \mathrm{E}$ Graben, because it is accompanied by a subsidence of approximately $500 \mathrm{~m}$ at the site. In contrast to the previous hiatus, it is observed on MCS data from the CKP and corresponds to erosion into Sequence P2. Thus, as postulated in the Raggatt Basin on the SKP (Coffin et al., 1990), this period of time seems also to correspond to a major change in the sedimentation processes. The breakup between the NKP and Broken Ridge dated at 43-42 Ma (Mutter and Cande, 1983; Munschy and Schlich, 1987) could explain this change by intensification of the physical oceanographic regime.

After $37.8 \mathrm{Ma}$, sediment sequences to the south of Heard Island contain prograding configurations and are cut by submarine channels possibly related to the formation of the island. The oldest volcanogenic sediments on Heard Island are Eocene (Quilty et al., 1983), a minimum age for the island. Initiation of Heard Island volcanism may be related to the breakup between the Kerguelen Plateau and Broken Ridge.

\section{CONCLUSIONS}

Seismic stratigraphic and tectonic interpretations of seismic data on the CKP correlated with ODP results at Site 747 allows construction of a model for the formation of this part of the Kerguelen Plateau and description of its evolution. The three main events that mark the formation and evolution of the CKP can be linked to the geodynamic evolution of the Indian Ocean.

The construction of the basement of the Kerguelen Plateau occurred between 120 and $110 \mathrm{Ma}$ at the axis of the spreading ridge that separated Antarctica-Australia from India. Such a huge amount of lava could be linked to large transform faults postulated to exist between Antarctica, Australia, and India (Fig. 8 of Powell et al., 1988) and to continental extension between Australia and Antarctica from middle Jurassic (160 Ma) to mid-Cretaceous ( $96 \mathrm{Ma}$ ) time. Moreover, the end of the erosion of the CKP basement and the first deposits linked to subsidence correspond to a major change in the spreading movement between India and Antarctica and to the end of the continental extension between Antarctica and Australia followed by seafloor spreading (Powell et al., 1988). However, these correlations are speculative because the age for the end of the erosional event on the CKP is based on an extrapolation of the sedimentation rates and the age of the change in spreading direction is not well constrained.

The east-west stretching of the CKP along the $77^{\circ} \mathrm{E}$ Graben mainly occurred at $72 \mathrm{Ma}$. This age corresponds to the younger edge of Magnetic Anomaly 32 following the geomagnetic reversal time scale of Berggren et al. (1985). Two recurrent faulting episodes began at 66 (Anomaly 29) and 53 Ma (Anomaly 22). The first and main event ( $72 \mathrm{Ma}$ ) can be associated with the beginning of the rapid northward flight of India, the spreading increasing from 50 to $110 \mathrm{~km} / \mathrm{m} . y$. (Patriat and Ségoufin, 1988) and to the initiation of the movement between Australia and Antarctica by seafloor spreading at a rate of $4 \mathrm{~km} / \mathrm{m}$.y (König, 1987). The correlation of the two other tectonic events observed on the CKP with variations of seafloor spreading is less evident; however, Anomaly 22 corresponds to a decrease of the spreading rate at the Southeast Indian Ridge from about 100 to about $40 \mathrm{~km} / \mathrm{m} . \mathrm{y}$.

The major hiatus between 52.6 and $37.8 \mathrm{Ma}$ appears to be the result of a modification of the currents linked to the initiation of seafloor spreading at the Southeast Indian Ridge.

The sedimentation and tectonic history of the CKP can be summarized in three phases: (1) a pre-rift tectonic period from 72 to $52 \mathrm{Ma}$, mainly characterized by stretching at $72 \mathrm{Ma}$; (2) breakup between the Kerguelen Plateau and Broken Ridge at $42 \mathrm{Ma}$, accompanied by a nonsedimentation period of about 15 m.y. or less duration; and (3) post-rift sedimentation that evolved during the Pliocene-Pleistocene in response to the climate changes.

\section{ACKNOWLEDGMENTS}

M. Munschy, R. Schlich, and M. F. Coffin thank the Ocean Drilling Program for inviting them to participate on Leg 120 on board the JOIDES Resolution. The authors thank E. Barbu, R. E. Houtz, B. R. Rosendahl, and S. W. Wise, Jr., for critical reviews and comments on the original version of the manuscript. We also thank Monique Blanck for drafting the figures. We are grateful to Territoire des Terres Australes et Antarctiques Françaises for their support on board Marion Dufresne during Cruise MD 47 in 1986. M. F. Coffin publishes with the permission of the Director, Bureau of Mineral Resources. 


\section{REFERENCES}

Aubry, M.-P., and Berggren, W. A., 1989. Age of the upper volcaniclastic debris flow at Site 747: a special study. In Schlich, R., Wise, S. W., Jr., et al., Proc. ODP, Init. Repts., 120: College Station, TX (Ocean Drilling Program), 57-72.

Badley, M. E., Price, J. D., Dahl, C. R., and Agdestein, T., 1988. The structural evolution of the northern Viking graben and its bearing upon extensional modes of basin formation. J. Geol. Soc. London, 145:455-472.

Berggren, W. A., Kent, D. V., Flynn, J. J., and Van Couvering, J. A., 1985. Cenozoic geochronology. Geol. Soc. Am. Bull., 96:14071418.

Coffin, M. F., Davies, H. L., and Haxby, W. F., 1986. Structure of the Kerguelen Plateau province from SEASAT altimetry and seismic reflection data. Nature, 324:134-136.

Coffin, M. F., Munschy, M., Colwell, J. B., Schlich, R., Davies, H. L., and Li, Z. G., 1990. Seismic stratigraphy of the Raggatt Basin: tectonic and paleoceanographic implications. Geol. Soc. Am. Bull., 102:563-579.

Colleta, B., Le Quellec, P., Letouzey, J., and Moretti, I., 1988. Longitudinal evolution of the Suez rift structure (Egypt). Tectonophysics, 153:221-233.

Eldholm, O., Thiede, J., Taylor, E., et al., 1987. Proc. ODP, Init. Repts., 104: College Station, TX (Ocean Drilling Program).

Houtz, R. E., Hayes, D. E., and Markl, R. G., 1977. Kerguelen Plateau bathymetry, sediment distribution and crustal structure. Mar. Geol., 25:95-130.

König, M., 1987. Geophysical data from the continental margin off Wilkes Land, Antarctica-Implications for breakup and dispersal of Australia-Antarctica. In Eittreim, S. L., and Hampton, M. A., The Antarctic Continental Margin: Geology and Geophysics of Offshore Wilkes Land. Circum-Pacific Council for Energy and Mineral Resources, Earth Sci. Ser., 5:117-145.

Li, Z. G., 1988. Structure, origine et évolution du plateau de Kerguelen [Thèse de Doctorat]. Univ. Louis Pasteur, Strasbourg, France.

Munschy, M., and Schlich, R., 1987. Structure and evolution of the Kerguelen-Heard Plateau (Indian Ocean) deduced from seismic stratigraphy studies. Mar. Geol., 76:131-152.

Mutter, J. C., and Cande, S. C., 1983. The early opening between Broken Ridge and Kerguelen Plateau. Earth Planet. Sci. Lett., 65:369-376.

Norton, I. O., and Sclater, J. G., 1979. A model for the evolution of the Indian Ocean and the break-up of Gondwanaland. J. Geophys. Res., 84:6803-6830.

Patriat, P., and Ségoufin, J., 1988. Reconstruction of the Central Indian Ocean. Tectonophysics, 155:211-234.

Powell, C. McA., Roots, S. R., and Veevers, J. J., 1988. Pre-breakup continental extension in East Gondwanaland and the early opening of the eastern Indian Ocean. Tectonophysics, 155:261-283.

Quilty, P. G., Shafik, S., McMinn, A., Brady, H., and Clarke, I., 1983. Microfossil evidence for the age and environment of depo- sition of sediments of Heard and McDonald islands. In Oliver, R. L., James, P. R., and Jago, J. B. (Eds.), Antarctic Earth Science. Cambridge (Cambridge Univ. Press), 636-639.

Ramsay, D. C., Colwell, J. B., Coffin, M. F., Davies, H. L., Hill, P. J., Pigram, C. J., and Stagg, H.M.J., 1986. New findings from the Kerguelen Plateau. Geology, 14:589-593.

Rosendahl, B. R., 1987. Architecture of continental rifts with special reference to East Africa. Annu. Rev. Earth Planet. Sci., 15:445503.

Rotstein, Y., Munschy, M., Schlich, R., and Hill, P. J., 1991. Structure and early history of the Labuan Basin, Southern Indian Ocean. J. Geophys. Res., 96:3887-3904.

Rotstein, Y., Schaming, M., Schlich, R., and Colwell, J. B., 1990. Basin evolution in oceanic volcanic plateaus: seismic reflection evidence from the Kerguelen Plateau, South Indian Ocean. Mar. Pet. Geol., 7:1-12.

Schaming, M., and Rotstein, Y., 1990. Basement reflectors in the Kerguelen Plateau, South Indian Ocean: indications for the structure and early history of the plateau. Geol. Soc. Am. Bull., 102:580-592.

Schlich, R., 1975. Structure et âge de l'océan Indien occidental. Mem. Hors-Ser. Soc. Geol. Fr., 6:1-103.

Schlich, R., Coffin, M. F., Munschy, M., Stagg, H.M.J., Li, Z. G., and Revill, K., 1987. Bathymetric chart of the Kerguelen Plateau. Jointly edited by the Bureau of Mineral Resources, Geology and Geophysics, Canberra, Australia, Institut de Physique du Globe, Strasbourg, France, and Territoire des Terres Australes et Antarctiques Françaises, Paris, France.

Schlich, R., Munschy, M., Boulanger, D., Cantin, B., Coffin, M. F., Durand, J., Humler, E., Li, Z. G., Savary, J., Schaming, M., and Tissot, J. D., 1988. Résultats préliminaires de la campagne océanographique de sismique réflexion multitraces MD47 dans le domaine sud du plateau de Kerguelen. C. R. Acad. Sci. Ser. 2., 305:635-642.

Scott, D. L., and Rosendahl, B. R., 1989. North Viking Graben: an East African perspective. AAPG Bull., 73:155-165.

Shipboard Scientific Party, 1989a. Site 747. In Schlich, R., Wise, S. W., Jr., et al., Proc. ODP, Init. Repts., 120: College Station, TX (Ocean Drilling Program), 89-156.

1989b. Site 748. In Schlich, R., Wise, S. W., Jr., et al., Proc. ODP, Init. Repts., 120: College Station, TX (Ocean Drilling Program), 157-235.

Vail, P. R., Mitchum, R. M., Jr., Todd, R. G., Widmier, J. M., Thompson, S., III, Sangree, J. B., Bubb, J. N., and Hatlelid, W. G., 1977. Seismic stratigraphy and global changes of sea level. In Payton, C. E. (Ed.), Seismic Stratigraphy: Applications to Hydrocarbon Exploration. AAPG Mem., 26:49-212.

Date of initial receipt: 30 August 1990

Date of acceptance: 20 February 1991

Ms 120B-125 